\title{
EVALUASI KEBIJAKAN PEMBEKALAN KEWIRAUSAHAAN APARATUR PRA PURNABAKTI DI LINGKUNGAN PEMERINTAH DAERAH PROVINSI JAWA BARAT
}

\author{
Oleh
}

\author{
Kellie Praja Putra ${ }^{1}$, \\ H. Khasan Effendy ${ }^{2}$, Rossy Lambelanova ${ }^{3}$ \\ ${ }^{1)}$ BKD Provinsi Jawa Barat \\ Program Magister Terapan Studi Pemerintahan Daerah Institut Pemerintahan Dalam Negeri \\ kelliepraja12@gmail.com \\ ${ }^{2,3)}$ Institut Pemerintahan Dalam Negeri
}

\begin{abstract}
$E$ ntrepreneurship Program is one of the efforts of the provincial government of West Java in order to prepare civil servant pre-retiremen to handle the retirement period. This Program is a form of policy of West Java provincial government which is governed by regulation of the governor of West Java number 70 year 2018 about welfare of civil servant in the local government of West Java province.

This research aims to evaluate the implementation of entrepreneurship program in the local government of West Java province, how to implement entrepreneurship program and form of entrepreneurship program that applies in the region of West java government Province. The research method used is qualitative. Data collection techniques are by conducting live observations, interviews, documentation and triangulation. Determination of informant using sampling purpose.

The results showed that the implementation of entrepreneurship program in West Java provincial government environment does not run optimally in West Java provincial government environment. This is demonstrated by several criteria of dimension, namely, effectiveness, efficiency, adequacy, equalization, and accuracy does not run optimally. Only resposiality is quite good because of the enthusiasm of the civil servant is very high in the implementation of entrepreneurship program. West Java provincial Government must change the pattern of entrepreneurship provision, because entrepreneurship program is a form of appreciation not the rights of civil servant. Advice from researchers is the provincial government of West Java Change Entrepreneurship program According to the interest of talent, and the selection of civil servant that really has the skills involved.
\end{abstract}

Keywords: evaluate of policy, entrepreneurship program, civil servant pre-retiremen

\footnotetext{
Abstrak

Drogram pembekalan kewirausahaan merupakan salah satu upaya Pemerintah Provinsi Jawa Barat dalam mempersiapkan aparatur pra purnabakti menghadapi masa pensiun. Program tersebut merupakan bentuk kebijakan Pemerintah Provinsi Jawa Barat yang di atur dalam Peraturan Gubernur Jawa Barat Nomor 70 Tahun 2018 tentang Kesejahteraan Aparatur di Lingkungan Pemerintah Daerah Provinsi Jawa Barat.
} 
Penelitian ini bertujuan untuk mengevaluasi pelaksanaan Program Pembekalan Kewirausahaan di Lingkungan Pemerintah Daerah Provinsi Jawa Barat,Bagaimana pelaksanaan program pembekalan kewirausahaan dan bentuk program pembekalan kewirausahaan yang bagaimana yang cocok diterapkan di Lingkungan Pemerintah Daerah Provinsi Jawa Barat. Metode penelitian yang digunakan adalah kualitatif. Teknik pengumpulan data adalah dengan melakukan pengamatan langsung, wawancara, dokumentasi dan triangulasi. Penentuan informan menggunakan purpose sampling.

Hasil penelitian menunjukkan bahwa pelaksanaan program pembekalan kewirausahaan di Lingkungan Pemerintah Daerah Provinsi Jawa Barat belum berjalan secara optimal diterapkan di lingkungan Pemerintah Provinsi Jawa Barat. Hal tersebut ditunjukkan oleh beberapa kriteria dimensi yakni, Efektivitas, Efisiensi, kecukupan, pemerataan, dan ketepatan belum berjalan secara optimal. Hanya saja resposivitas peserta yang sudah cukup baik karena antusias aparatur sangat tinggi setiap pelaksanaan program pembekalan kewirausahaan. Pemerintah Provinsi Jawa Barat harus merubah pola pembekalan kewirausahaan, karena program pembekalan kewirausahaan adalah suatu bentuk penghargaan bukan suatu hak dari setiap aparatur. Saran dari peneliti adalah pemerintah Provinsi Jawa Barat merubah program pembekalan kewirausahaan sesuai dengan minat bakat, dan menyeleksi aparatur yang betulbetul memiliki keterampilan berwirausaha yang diikutsertakan.

Kata kunci: evaluasi kebijakan, pembekalan kewiraushaan, aparatur pra purnabakti

\section{PENDAHULUAN}

$\mathrm{B}$ erdasarkan Undang-Undang No. 5 Tahun 2014 tentang Aparatur Sipil Negara, Aparatur Sipil Negara yang selanjutnya disingkat ASN adalah profesi bagi pegawai negeri sipil dan pegawai pemerintah dengan perjanjian kerja yang bekerja pada instansi pemerintah. Pegawai Aparatur Sipil Negara yang selanjutnya disebut pegawai ASN adalah pegawai yang diangkat oleh pejabat pembina kepegawaian dan diserahi tugas dalam suatu jabatan pemerintahan atau diserahi tugas negara lainnya dan digaji berdasarkan peraturan perundangundangan.

Undang-Undang Nomor 5 Tahun 2014 tentang Aparatur Sipil Negara dijelaskan pada Pasal 90 bahwa batas usia pensiun sebagaimana dimaksud dalam Pasal 87 ayat huruf c, yaitu: 58 (lima puluh delapan) tahun bagi pejabat administrasi, 60 (enam puluh) tahun bagi pejabat pimpinan tinggi, dan sesuai dengan ketentuan peraturan perundang-undangan bagi pejabat fungsional.
Aparatur Sipil Negara yang bertugas mengabdi kepada negara setelah memasuki purnabakti tentunya mendapatkan hak pensiun seperti dijelaskan pada Pasal 21 PNS berhak memperoleh:

a. gaji, tunjangan, dan fasilitas;

b. cuti:

c. jaminan pensiun dan jaminan hari tua;

d. perlindungan;dan

e. pengembangan kompetensi

Mengacu kepada Undang-undang tersebut, Pemerintah provinsi Jawa Barat menetapkan Peraturan Gubernur No 70 Tahun 2018 tentang kesejahteraan aparatur di lingkungan Pemerintah Daerah Provinsi Jawa Barat, memberikan payung hukum kepada aparatur pra purnabakti untuk memperoleh salah satu bentuk kesejahteraan yakni berupa kebijakan disertai bantuan rintisan usaha.

Pemerintah provinsi Jawa Barat di bawah pengelolaan Badan Kepegawaian Daerah membuat suatu kebijakan yang ditujukan kepada aparatur yang akan memasuki purnabakti, aparatur yang akan memasuki 
purnabakti diberikan pelatihan selama empat hari untuk mempersiapkan masa pensiun serta diberikan biaya rintisan usaha. Hal tersebut dijelaskan pada Peraturan Gubernur Jawa Barat No. 70 Tahun 2018 tentang kesejahteraan aparatur Pasal 14, yaitu sebagai berikut.

1. Dalam rangka meningkatkan jiwa kewirausahaan di kalangan Aparatur, dilaksanakan pembekalan kewirausahaan.

2. Pembekalan kewirausahaan sebagaimana dimaksud pada ayat (a), diselenggarakan oleh Badan.

3. Aparatur yang akan mengikuti pembekalan kewirausahaan sebagaimana dimaksud ayat (b), harus menyampaikan proposal rintisan usaha.

4. Aparatur yang telah mengikuti kursus dan pelatihan kewirausahaan sebagaimana dimaksud pada ayat (b) dan ayat (c), langsung diberikan biaya rintisan usaha.

5. Biaya rintisan usaha sebagaimana dimaksud pada ayat (d), diberikan sebesar Rp25.000.000,00 (dua puluh lima juta rupiah) yang dianggarkan pada Perangkat Daerah masing-masing

Pensiun atau purnabakti adalah tahap akhir dari pengabdian seorang Pegawai Negeri Sipil, pada tahap ini pegawai akan meninggalkan karier, kelekatan dengan organisasi dan menghadapi tekanan masa pensiun baik secara fisik, psikologis maupun sosial. Pada saat memasuki masa pensiun, pegawai rentan terhadap permasalahan yang timbul akibat transisi dari masa bekerja ke masa pensiun.

Masa Purnabakti bagi aparatur merupakan suatu kondisi di mana tidak ada lagi pekerjaan, tugas dan kegiatan yang biasa di lakukan secara rutinitas ketika masih aktif dalam dunia pekerjaan. Hal tersebut akan menimbulkan ketidakseimbangan dalam kehidupan sehari-hari, baik secara mental maupun secara jasmani. Kegiatan yang biasa di lakukan oleh aparatur yang masih aktif, yaitu berangkat pagi pulang sore. Bahkan hingga larut malam yang di lakukan selama lima hari kerja dalam seminggu, harus berhenti secara total dari kebiasaan tersebut. Istilah tersebut muncul untuk setiap orang yang mengalami gangguan psikologis yang disebabkan oleh depresi atau stres dalam menghadapi masa pensiun yang disebut dengan Post Power Syndrom.

Memasuki purnabakti adalah bagian dari karier kehidupan yang memerlukan penyesuaian skills, knowledges, attitudes supaya tetap menjadi pribadi yang sehat dan tetap produktif. Untuk mengantisipasinya, diperlukan sebuah perencanaan pribadi yang terpadu supaya ketika memasuki purnabakti menjadi proses yang terasa alami, penuh optimis, membawa harapan baru. Untuk itu perlu diubah mindset aparatur yang akan memasuki purnabakti. Perlu ditanamkan optimisme bahwa purnabakti adalah "masa keemasan" dan bukan "masa yang penuh kesuraman".

Pembekalan Kewirausahaan bagi Aparatur Pra Purnabakti di Lingkungan Pemerintah Daerah Provinsi Jawa Barat mempunyai maksud untuk memberikan bekal kemampuan, sikap dan keterampilan dalam bidang peningkatan motivasi dan kesejahteraan bagi pegawai menuju kemandirian finansial di masa purnabakti yang lebih sehat dan produktif. Adapun tujuannya adalah: memperkuat kesiapan fisik, mental-spiritual pegawai memasuki masa purnabakti, mengembangkan wawasan berbisnis di hari tua, membantu menyusun rencana menyeluruh pribadi di masa purnabakti, dan mengembangkan bakat dan minat dalam meraih kemandirian finansial di masa purnabakti. Untuk mencapai tujuan tersebut maka ditetapkan sasaran sebagai berikut.

1. Adanya perubahan mindset dari para Aparatur Pra Purnabakti bahwa pensiun 
adalah peluang untuk mewujudkan potensi yang selama ini dimiliki namun belum berkembang karena rutinitas sebagai pegawai.

2. Adanya peningkatan wawasan mengenai kewirausahaan.

3. Meningkatnya wawasan dan pemahaman tentang pentingnya memelihara sikap mental peningkatan motivasi dan kesejahteraan dan berpandangan jauh ke depan sebagai bekal menjalani dan menghadapi pensiun

Dalam Modul Knowledge Second Carrier Training and Education Kebijakan (Pembekalan Kewirausahaan Aparatur Pra purnabakti) tahun 2019, ruang lingkup Pembekalan Kewirausahaan Aparatur Pra Purnabakti mencakup pendalaman tentang capacity building dan keterampilan usaha. Adapun Capacity Building mencakup: memelihara spiritualitas dan daya hidup, perencanaan karier di masa purnabakti, membangun jiwa entrepreneurship, mengubah masalah menjadi berkah, spirit menjemput masa depan, bekerja benar dengan ihtiar dan bekerja cerdas penuh kreativitas. Sedangkan untuk keterampilan usaha mencakup: bisnis distribusi dan eceran, budi daya perikanan unggulan, budi daya komoditas pertanian unggulan, budi daya peternakan unggulan, klinik konsultasi usaha, komunikasi bisnis, manajemen pemasaran, pengolahan hasil pertanian, perikanan dan peternakan, solusi memilih bidang usaha, sumber-sumber permodalan, usaha jasa keuangan serta penyusunan proposal usaha. Materi-materi tersebut diberikan oleh narasumber ahli yang kompeten di bidangnya, yang berasal dari perguruan tinggi, perbankan dan praktisi.

Data yang di peroleh hasil wawancara dengan pengelola kebijakan pembekalan kewirausahaan, pada awalnya pembekalan Kewirausahaan di lingkungan Pemerintah Daerah ProvinsiJawa Baratdilaksanakan pada tahun 2008 dengan tambahan pemberian uang saku bagi peserta sebesar Rp.50.000 per hari. Pelaksanaan kebijakan pembekalan pada waktu itu dengan jumlah peserta yang sedikit dan tidak memenuhi kuota. Lalu pada tahun 2010, kebijakan pembekalan dilaksanakan dengan tambahan pemberian bantuan usaha sebesar Rp2.500.000 untuk masing-masing peserta yang telah mengikuti pembekalan kewirausahaan. Dengan adanya pemberian bantuan usaha tersebut, kebijakan pembekalan mulai banyak diminati oleh para aparatur pra purnabakti sehingga memenuhi kuota peserta. Pada tahun 2014, sesuai dengan Peraturan Gubernur Jawa Barat Nomor 71 Tahun 2013 yang telah di perbaharui menjadi Peraturan Gubernur Jawa Barat Nomor 70 Tahun 2018 tentang Kesejahteraan Pegawai di Lingkungan Pemerintah Provinsi Jawa Barat, kebijakan pembekalan kewirausahaan dilaksanakan dengan tambahan pemberian bantuan usaha sebesar Rp25.000.000. Menurut pengelola kebijakan pembekalan kewirausahaan dengan adanya pemberian bantuan usaha, aparatur yang ingin mengikuti kebijakan pembekalan melonjak tinggi melebihi kouta yang telah ditetapkan, serta aparatur pra purnabakti cenderung berebut untuk segera diikutsertakan meskipun masa purnabakti masih lama.

Biaya rintisan usaha yang di berikan kepada aparatur yang memasuki purnabakti tentunya mendapatkan perhatian dari seluruh aparatur karena biaya rintisan tersebut cukup besar. Namun kebijakan pembekalan kewirausahaan tersebut belum sepenuhnya berjalan secara maksimal, hal tersebut dibuktikan dari hasil wawancara dengan aparatur yang telah mendapatkan biaya rintisan usaha. Dari hasil wawancara dengan aparatur yang telah mendapatkan biaya rintisan usaha pada 28 Februari 2019, uang rintisan usaha tersebut digunakan untuk keperluan anaknya salah satu contohnya untuk membeli kendaraan motor. Dengan demikian, biaya rintisan usaha tidak digunakan sebagaimana mestinya. 


\section{KAJIAN PUSTAKA}

\section{Kebijakan Publik}

Kebijakan publik menurut Thomas Dye dalam Understanding Public Policy (1987:17) adalah apa pun pilihan pemerintah untuk melakukan atau tidak melakukan (public policy is whatever government choose to do or not to do). Konsep tersebut sangat luas karena kebijakan publik mencakup sesuatu yang tidak dilakukan oleh pemerintah di samping yang dilakukan oleh pemerintah ketika pemerintah menghadapi suatu masalah publik. Sedangkan menurut chiff J.o Udaji dalam Abdul Wahab (2001:5) mendefinisikan kebijakan publik atau kebijakan Negara sebagai "an sanctioned course of action addressed to particular problem or group of related problems that affect society at large". (Suatu tindakan bersanksi yang mengarah pada suatu masalah atau kelompok masalah tertentu yang saling berkaitan memengaruhi sebagian besar masyarakat).

Selanjutnya menurut Dye dalam Thoha (2002:4) mengemukakan bahwa kebijakan sebagai "a set of interreleated decision taken by a political actor or group of actors concerning the selection of goals and the means of achieving them within a specified situation where these decision should in principle, be within the power of these actors to achieve". Kebijakan adalah serangkaian keputusan yang saling berkaitan yang diambil oleh seorang aktor politik berkenaan dengan tujuan yang telah dipilih beserta cara-cara mencapainya dalam situasi di mana keputusan-keputusan itu pada prinsipnya masih berada dalam batas-batas kewenangan aktor tersebut.

Kemudian menurut Harold D Laswell dan Abraham Kaplan dalam Islamy (1984:16) mengatakan bahwa kebijakan publik sebagai "a projected program of goals, values dan practices" ( Suatu program pencapaian tujuan, nilai-nilai dan praktik-praktik yang terarah) Amara Raksasataya dalam Islamy (1984:17-18) juga mengemukakan bahwa "kebijaksanaan publik sebagai suatu taktik dan strategi yang diarahkan untuk mencapai suatu tujuan". Oleh karena itu suatu kebijaksanaan memuat 3 elemen, yaitu sebagai berikut.

a. Identifikasi dari tujuan yang ingin dicapai;

b. Taktik atau strategi dari berbagai langkah untuk mencapai tujuan yang diinginkan;

c. Penyediaan berbagai input untuk memungkinkan pelaksanaan secara nyata dari taktik atau strategi.

Menurut Dunn (2003:132) menyatakan bahwa "kebijakan publik (Public policy) adalah pola ketergantungan yang kompleks dari pilihan-pilihan kolektif yang saling bergantung, termasuk keputusan-keputusan untuk tidak bertindak, yang dibuat oleh badan atau kantor pemerintah". Sedangkan menurut Raharjo (2011.113) mengatakan bahwa "kebijakan publik adalah tindakan yang memiliki tujuan tertentu, yang dilaksanakan oleh instansi-instansi pemerintah beserta jajarannya dan masyarakat untuk mencegah sesuatu masalah tertentu".

\section{Evaluasi}

Secara harfiah, evaluasi berasal dari bahasa Inggris, yakni evaluation, yang berarti penilaian atau penaksiran (John M Echools dan Hasan Shadily, 1983). Stufflebeam (1971) dalam Arikunto (2009:5) mendefinisikan " evaluation is the process of delineating, obtaining and providing useful information for judging decision alternatives (Evaluasi adalah proses menggambarkan, memperoleh dan menyajikan informasi yang berguna untuk merumuskan suatu alternatif keputusan)".

Menurut Joyce Provus (1975:39) "evaluasi adalah suatu kegiatan untuk membandingkan antara capaian program dengan tujuan yang telah ditetapkan sebelumnya". Sedangkan menurut 
Munthe (2015:3) "evaluasi program dapat disimpulkan sebagai suatu proses pencarian informasi, penemuan informasi dan penetapan informasi yang dipaparkan secara sistematis tentang perencanaan, nilai tujuan, manfaat, efektivitas dan kesesuaian suatu dengan kriteria dan tujuan yang telah ditetapkan".

Cronbach sebagaimana yang dikutip oleh Egon G Guba (1983) mengemukakan tiga hal yang berkaitan dengan pengertian evaluasi, "pertama apabila evaluasi menjadi prioritas utama bagi penyelenggaraan, maka harus difokuskan pada keputusan yang telah diambil pada kurun waktu itu dan perkembangan yang telah terjadi, kedua evaluasi harus fokus pada kemungkinan modifikasi dan pengembangan pada performansi karakteristik kegiatan dari pada membandingkan dengan suatu standar".

Menurut William N Dunn (1999) menyatakan bahwa di dalam evaluasi terdapat enam indikator, yaitu sebagai berikut.

1. Efektivitas, berkenaan dengan apakah suatu alternatif mencapai hasil (akibat) yang diharapkan atau mencapai tujuan dari diadakannya tindakan. Efektivitas yang secara dekat berhubungan dengan rasionalitas teknis selalu diukur dari produk atau layanan atau nilai moneternya;

2. Efisiensi, berkenaan dengan jumlah usaha yang diperlukan untuk menghasilkan tingkat efektivitas tertentu. Efisiensi yang merupakan sinonim dari rasionalitas ekonomi adalah merupakan hubungan antara efektivitas dan usaha yang terakhir umumnya diatur dari ongkos monoter;

3. Kecukupan, berkenaan dengan seberapa jauh suatu tingkat Efektivitas memuaskan kebutuhan, nilai atau kesempatan yang menumbuhkan adanya masalah. Kriteria kecukupan menekankan pada kuatnya hubungan antara alternatif kebijakan dan hasil yang diharapkan;

4. Pemerataan, erat berhubungan dengan rasionalitas legal dan sosial serta merujuk kepada distribusi akibat dari usaha antarkelompok yang berbeda dalam masyarakat. Kebijakan yang berorientasi kepada keadilan adalah kebijakan yang akibatnya atau usaha secara adil didistribusikan;

5. Responsivitas, berkenaan dengan seberapa jauh kebijakan dapat memuaskan kebutuhan, preferensi, nilai kelompok-kelompok masyarakat tertentu. Kriteria responsivitas adalah penting karena analis yang dapat memuaskan kriteria lainnya (efektivitas, efisiensi, kecukupan dan pemerataan) masih gagal jika beluk menanggapi semua kebutuhan actual dari kelompok yang semestinya diuntungkan dari suatu kebijakan;

6. Ketepatan, yaitu secara dekat berhubungan dengan rasionalitas substantif, karena pertanyaan tentang ketepatan kebijakan tidak berkenaan dengan satuan kriteria individu tetapi dua atau lebih kriteria secara bersamasama. Ketepatan merujuk kepada kuatnya asumsi yang melandasi tujuan-tujuan tersebut. Kriteria kelayakan biasanya bersifat terbuka, karena pendefinisian ini dimaksudkan untuk menjangkau keluar kriteria yang telah ada.

Dalam bukunya, Designing evaluator of educationl and social programme, Cronbach (1960) memberikan uraian mengenai prinsip-prinsip dasar evaluasi adalah sebagai berikut.

1. Evaluasi program pendidikan merupakan kegiatan yang dapat membantu pemerintah dalam mencapai tujuan-tujuannya;

2. Evaluasi merupakan suatu seni dan tidak ada satu pun evaluasi yang sempurna, 
walaupun dilakukan dengan teknik yang berbeda-beda;

3. Evaluasi merupakan suatu proses terus menerus, sehingga di dalam proses kegiatannya dimungkinkan untuk merevisi bila dirasakan adanya sesuatu kesalahan.

Menurut Kirkpatrick (Implementing The Four Level, 2007:23) evaluasi ini menggambarkan program pelatihan yang dapat dievaluasi dengan empat tahap evaluasi, yaitu Reaction, Learning, Behaviour, dan Result. Keempat tahapan evaluasi dari Kirkpatrick tersebut harus dilakukan secara simultan untuk menghasilkan evaluasi yang diharapkan. Keempat tahap tersebut adalah sebagai berikut.

1. Reaction (Reaksi) adalah lembaran kepuasan pelanggan (costumer satisfaction sheet), karena bertujuan untuk mendapatkan masukan dan komentar peserta terhadap program pembekalan atau pembekalan dan berdasarkan kepuasan peserta terhadap pelayanan dari panitia penyelenggara, instruktur pembekalan (narasumber), dan fasilitas yang mereka terima.

2. Learning (Tingkatan Pembelajaran) adalah proses interaksi antara peserta dan pemberi materi pada suatu proses pembelajaran. Pembelajaran, yaitu untuk mempermudah peserta dalam memperoleh ilmu pengetahuan, keterampilan, serta perubahan behaviour ke dalam kegiatan sehari-hari.

3. Behaviour (perilaku) Perilaku merupakan respons atau reaksi seseorang terhadap rangsangan dari luar (Stimulus).

4. Result (Dampak) adalah benturan, pengaruh yang mendatangkan akibat baik positif maupun negatif. Pengaruh adalah suatu keadaan di mana ada hubungan timbal balik atau hubungan sebab akibat antara apa yang memengaruhi dengan apa yang dipengaruhi.

Dari pengertian-pengertian evaluasi yang telah dikemukakan oleh beberapa ahli di atas, dapat disimpulkan bahwa evaluasi adalah sebuah proses merencanakan, memperoleh dan menyediakan informasi yang sangat diperlukan untuk melihat sejauh mana keberhasilan sebuah program kegiatan. Keberhasilan suatu program itu dapat ditentukan dari hasil yang telah dicapai oleh suatu program tersebut. Dalam hal ini, kebijakan Pemerintah Provinsi Jawa Barat menyelenggarakan Program Pembekalan Kewirausahaan tentunya memiliki maksud untuk mempersiapkan aparatur dalam menghadapi purnabakti.

Pada penelitian kali ini penulis memilih menggunakan teori dari William N Dunn, di mana terdapat enam indikator untuk melakukan evaluasi, yaitu effectiveness, efficiency, adequacy, equity, responsiveness, dan appropriateness. Dengan menggunakan enam indikator tersebut penulis dapat mengetahui masalah-masalah yang terjadi sesuai dengan informasi yang di sampaikan oleh panitia, peserta, narasumber, dan praktisi.

\section{Pembekalan Kewirausahaan}

Menurut Retno Dewanti dalam bukunya Kewirausahaan (2008) Kewirausahaan adalah keterampilan yang dapat dipelajari dan dikembangkan. Oleh karena itu sebelum menjadi wirausahawan dapat mempertimbangkan manfaat menjadi wirausahawan dan menjadi pemilik bisnis. Manfaat itu antara lain sebagai berikut.
a. Peluang mengendalikan sendri
b. Kesempatan melakukan perubahan
c. Peluang untuk menggunakan potensi sepenuhnya


d. Peluang untuk meraih keuntungan tanpa batas

e. Peluang untuk berperan bagi masyarakat dan mendapatkan pengakuan atas usaha sendiri;

f. Peluang melakukan sesuatu yang disukai Selain itu menurutnya wirausahawan mempunyai kelemahan, proses kewirausahaan dan tahapan-tahapan yang harus di lakukan oleh wirausahawanan, berikut penjelasannya.

\section{- Kelemahan Menjadi Wirausahawan}

a. Pendapatan yang tidak pasti: usaha yang dijalankan belum memberikan kepastian akan jaminan cukup uang untuk hidup sesuai dengan yang diinginkan. Pemilik adalah orang terakhir mendapatkan gaji, tetapi menjadi orang pertama yang menanggung kerugian.

b. Risiko kehilangan seluruh Investasi: Tingkat kegagalan bisnis relatif tinggi, $51 \%$ tutup dalam waktu 4 tahun, dan $63 \%$ gulung tikar setelah 6 tahun. Penelitian ini membuktikan bahwa wirausahawan patut mempersiapkan diri secara psikologis dampak kegagalan.

c. Kerja lama dan kerja keras: membutuhkan tenaga ekstra di saat pegawai lain tidak bekerja karena harus mampu memberikan waktu lebih dari yang diharapkan pelanggannya dan rell untuk tidak menerima upahnya. Bersedia bekerja keras.

d. Mutu hidup yang rendah sampai bisnisnya mapan: waktu yang panjang tersita hanya untuk bisnis dan sering kali keluarganya terabaikan.

e. Ketegangan mental yang tinggi: Ketegangan mental terjadi akibat penanaman modalyang berdampak pada kekhawatiran akan pengelolaannya.
Frustasi sering diderita tatkala lingkungan ekonomi melemahkan kekuatan modalnya.

f. Tanggung jawab penuh; Kemampuan menguasai keahlian hanya tertentu saja dan tidak di semua bidang, oleh karena itu keputusan sering kali membebaninya dengan ketidakyakinan atas hasil. Biasanya kurang pengalaman dan pengetahuan

\section{- Proses Kewirausahaan}

Kewirausahaan diawali dengan inovasi yang dipicu oleh faktor pribadi, lingkungan dan sosiologinya. Perintisan kewirausahaan dipicu oleh ketiga faktor tersebut.

A. Faktor Pribadi
a) Pencapaian locus of control: pengendalian mental
b) Toleransi: menghargai orang lain
c) Pengambilan risiko: memperhitungkan risiko
d) Nilai-nilai pribadi: prinsip diri, agama, budaya
e) Pendidikan: pengetahuan dan implementasinya
f) Pengalaman: pengamatan dan pengalaman pribadi
g) Ketidakpuasan: tidak berpuas diri
h) Usia: semangat, kekuatan dan fisik
i) Komitmen: kesanggupan

B. Faktor lingkungan yang berpengaruh:
a) Peluang: situasi menguntungkan
b) Model peranan: tanggung jawab masing-masing di lingkungannya
c) Aktivitas: koordinasi
d) Pesaing: industri yang sama
e) Inkubator: sumber ide 
f) Sumber daya: alam, manusia, teknologi

g) Kebijakan pemerintah: peraturan bisnis

\section{- Tahapan Kewirausahaan}

Kewirausahaan dimulai dengan tahap perintisan. Wirausahaan menciptakan ide sehingga penting untuk mempersiapkan perencanaan pokok ke arah pencapaian tujuan. Ide yang berhasil adalah ide yang mempertimbangkan inovasi. Lima macam pembedaan inovasi oleh Joseph Shumpeter dalam buku Retno Dewanti (kewirausahaan: 2008) yakni:

a) Inovasi diartikan memproduksi sesuatu benda yang kualitasnya berbeda

b) Inovasi diartikan memproduksi sesuatu benda dengan cara yang baru yang belum pernah dirintis siapa pun juga

c) Inovasi diartikan memasuki pasar baru yang belum pernah dimasuki industri tertentu

d) Inovasi diartikan menggunakan bahanbahan baku atau barang setengah jadi yang belum dipergunakan oleh suatu industri

e) Inovasi diartikan mengorganisasikan produksi dalam bentuk baru.

Menurut Iswanti (2014:96) terdapat enam materi pelatihan menghadapi pensiun, yaitu sebagai berikut.

1. Kondisi fisik dan kesehatan pada masa pensiun, meliputi penyakit atau gangguan kesehatan pada masa pensiun, cara menjaga kesehatan, dan penggunaan asuransi kesehatan

2. Kondisi psikologis di masa pensiun, meliputi pikiran (ingatan), perasaan (emosi), sikap (tingkah laku), serta cara menjaga kesehatan psikologis di masa lanjut usia
3. Aktivitas sosial di masa pensiun, meliputi pengisian waktu luang, aktivitas yang bersifat sosial ekonomi dan keagamaan, serta mengikuti organisasi pensiunan

4. Kondisi ekonomi pasca pensiun, meliputi kondisi keuangan di masa pensiun, cara mengelola uang TASPEN dan uang pensiun, menambah penghasilan di masa pensiun (kewirausahaan), permodalan dan passive income

5. Aktivitas keagamaan di masa pensiun, meliputi program-program keagamaan yang perlu diikuti

6. Kunjungan atau praktik lapangan pada usaha-usaha yang dapat dilakukan di masa pensiun meliputi usaha agrobisnis, industri rumah tangga (makanan, pakaian, barang kerajinan), jasa seperti biro perjalanan, makelaran, fotografi, dan bengkel. Kunjungan atau praktik lapangan tersebut ditindaklanjuti dengan pendampingan usaha dengan minat masing-masing.

Berdasarkan penjelasan di atas dapat disimpulkan bahwa program pembekalan kewirausahaan merupakan suatu kegiatan past service training yang dilaksanakan oleh Perangkat Daerah, yaitu Badan Kepegawaian Daerah Provinsi Jawa Barat yang bertujuan untuk mempersiapkan aparatur menghadapi purnabakti. Terdapat empat aspek penting yang harus disiapkan oleh aparatur dalam menghadapi purnabakti di antaranya adalah materi finansial, fisik, mental, emosi dan keluarga. Semakin baik persiapan yang dipersiapkan oleh aparatur dalam menghadapi pensiun, maka semakin baik pula aparatur dalam pensiun nanti

Materi program pembekalan kewirausahaan yang dilakukan oleh Badan Kepegawaian daerah Provinsi Jawa Barat meliputi psikologi, keuangan, kondisi fisik, pembekalan wirausaha oleh praktisi, dan field trip (kunjungan ke lapangan). 


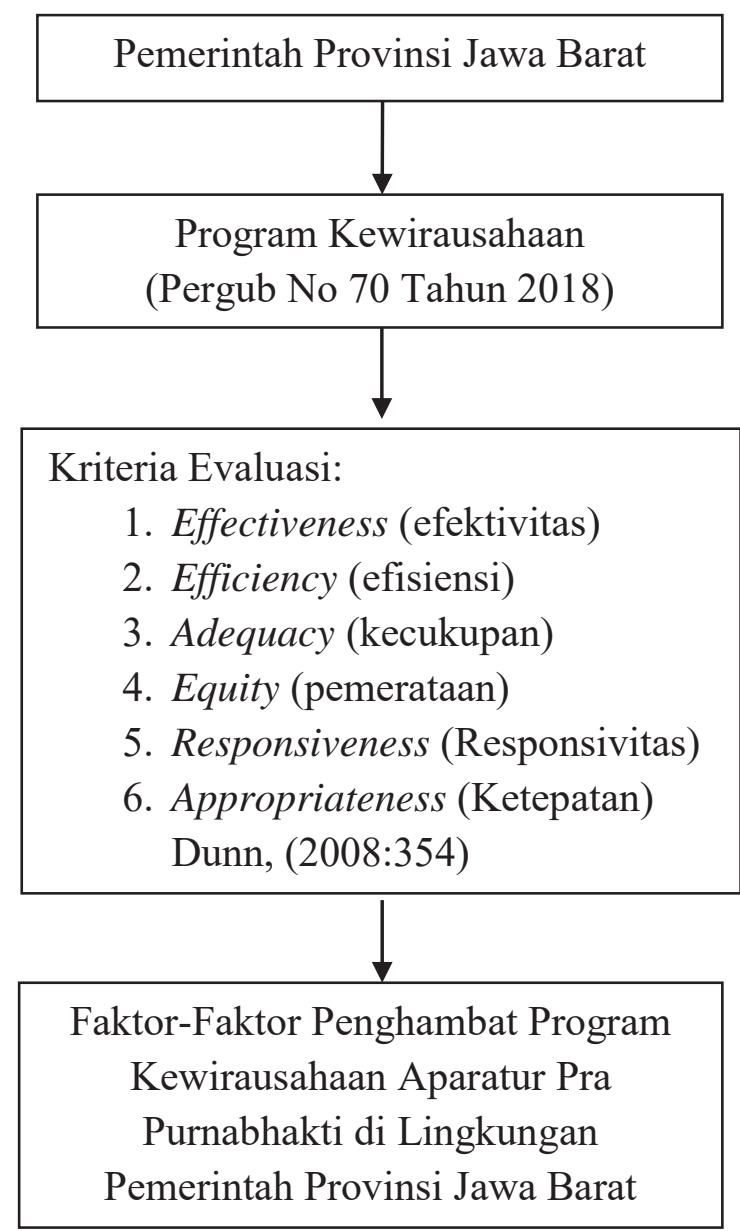

\section{Gambar 1}

Model Kerangka Pemikiran

Sumber: Diolah Peneliti, 2020

\section{METODE PENELITIAN}

Secara konseptual, penelitian ini menggunakan sejumlah konsep kunci sebagaimana dapat digambarkan dalam judul penelitian ini. Beberapa konsep kunci yang digunakan dalam penelitian ini adalah:

Pertama konsep "evaluasi Kebijakan" merujuk kepada pengertian dari pengumpulan informasi-informasi dan penjajagan informasi untuk memutuskan dan mengetahui cara yang lebih efektif dalam menggunakan sumber-sumber pembekalan yang tersedia sehingga mencapai tujuan pembekalan secara keseluruhan. Dengan melakukan evaluasi
Kebijakan dapat diketahui efektivitas dan efisiensi kegiatan pembekalan yang telah dilaksanakan oleh Badan Kepegawaian Daerah Provinsi Jawa Barat di Lingkungan Pemerintah Daerah Provinsi Jawa Barat. Selain itu evaluasi juga dapat mengetahui gambaran tentang sejauh mana keberhasilan aparatur yang telah mengikuti kegiatan pembekalan kewirausahaan, hambatan-hambatan yang dirasakan oleh peserta, kelemahankelemahan dan kelebihan oleh seluruh aparatur setelah mengikuti pembekalan.

Kedua, istilah "Kewirausahaan" merujuk kepada mereka yang akan memasuki masa pensiun yang memiliki kompetensi dan kemampuan untuk melihat dan menilai kesempatan-kesempatan bisnis dengan cara mengumpulkan sumber daya yang dibutuhkan untuk mengambil tindakan yang tepat dan mengambil keuntungan dalam rangka meraih sukses.

Menurut Suryana (2013:91) kompetensi yang harus dimiliki oleh wirausahawanan, yaitu:

\section{Manager Skill;}

2. Conceptual Skill;

3. Human skill;

4. Decision making skill;

5. Time Managerial Skill.

Ketiga, istilah "pembekalan kewirausahaan" merujuk kepada pelatihan untuk investasi SDM (Human Investment) dalam meningkatkan kemampuan dan keterampilan kerja dan dengan demikian meningkatkan kinerja pegawai. Dalam menghadapi masa pensiun aparatur di berikan pembekalan meliputi kesiapan mental, fisik, finansial, keterampilan dan dukungan keluarga.

Keempat, istilah "aparatur pra purnabakti” merujuk kepada mereka yang akan memasuki masa pensiun baik itu pejabat struktural eselon II, eselon III, eselon IV dan Pelaksana yang merupakan aparatur 


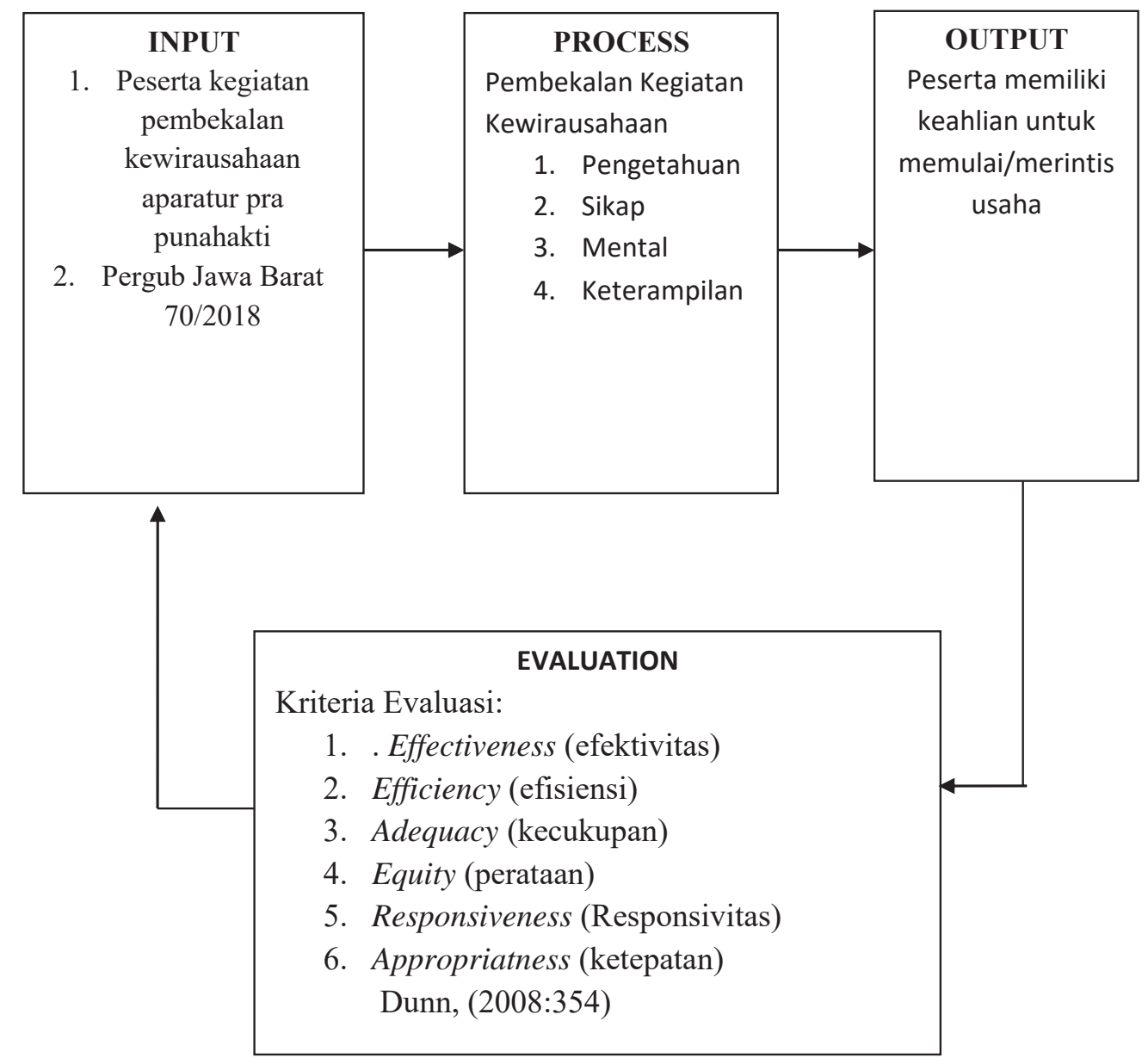

\section{Gambar 2}

Kerangka Konseptual Penelitian

\section{Sumber: Subbidang Kesejahteraan Pegawai}

di lingkungan Pemerintah Daerah Provinsi Jawa Barat. Sejak keseluruhan Kebijakan kegiatan pembekalan kewirausahaan diluncurkan tanggal 30 Juni 2008 telah dihasilkan alumni kegiatan kewirausahaan sebanyak 3.534 (tiga ribu lima ratus tiga puluh empat) orang.

Berdasarkan uraian di atas, maka penulis menyusun kerangka konseptual berdasarkan penelitian yang penulis lakukan, yaitu Evaluasi Kebijakan Pembekalan Kewirausahaan Aparatur Pra Purnabakti di Lingkungan Pemerintah Daerah Provinsi Jawa Barat Strategi sebagaimana tampak pada gambar 2 di atas.

\section{HASIL PENELITIAN}

Program Pembekalan Kewiraushaan Aparatur Pra Purnabakti di Lingkungan Pemerintah Daerah Provinsi Jawa Barat merupakan program unggulan di pemerintah Provinsi Jawa Barat dan satu-satunya di Indonesia di mana aparatur yang akan purnabakti di berikan pembekalan untuk mempersiapkan masa pensiun, sehingga ketika pensiun aparatur memiliki karier kedua, yaitu menjadi wirausahawan.

Pembahasan lebih mendalam tentang Evaluasi Program Pembekalan Kewirausahaan Aparatur pra Purnabakti di lingkungan Pemerintah Daerah Provinsi 
Jawa Barat, dalam penelitian ini dibahas dengan menggunakan enam kriteria evaluasi menurut Dunn (2003:429), adapun penjelasannya sebagi berikut.

\section{Effectiveness (Efektivitas)}

Bahwa pelaksanaan program pembekalan kewirausahaan belum sepenuhnya berjalan efektif, di mana aparatur yang sudah pensiun tidak semuanya dapat berwirausaha karena berbagai faktor dan hambatan dari masingmasing aparatur. Hal tersebut dijelaskan menurut Munthe (2015:3) "evaluasi program dapat disimpulkan sebagai suatu proses pencarian informasi, penemuan informasi dan penetapan informasi yang dipaparkan secara sistematis tentang perencanaan, nilai tujuan, manfaat, efektivitas dan kesesuaian suatu dengan kriteria dan tujuan yang telah ditetapkan".

\section{Efficiency (Efisiensi)}

Masih lemahnya pengawasan atau tindak lanjut dari pemerintah bagi aparatur yang telah mendapatkan biaya rintisan usaha, sehingga aparatur yang telah mendapatkan biaya rintisan usaha menggunakan sesuai kebutuhan bukan sesuai tujuan program tersebut. Selama ini pemberian biaya rintisan usaha dianggap sebagai hak dari semua aparatur, karena hampir semua aparatur yang pensiun mendapatkan uang rintisan tersebut. Biaya rintisan usaha yang di berikan pemerintah kepada aparatur cukup besar, sehingga program tersebut belum efisien karena masih kurang maksimalnya usaha yang di lakukan untuk melakukan pengawasan bagi aparatur yang telah mendapatkan biaya rintisan. Hal tersebut sesuai dengan teori Arifin (2013:5) "evaluasi adalah suatu proses yang sistematis dan berkelanjutan untuk menentukan kualitas (nilai dan arti) dari pada sesuatu, berdasarkan pertimbangan dan kriteria tertentu dalam rangka mengambil suatu keputusan". Hal tersebut disebabkan oleh aparatur yang telah mendapatkan biaya rintisan usaha tidak menggunakan biaya rintisan usaha sebagaimana mestinya.

\section{Adequacy (kecukupan)}

Kondisi di lapangan menunjukkan bahwa sampai saat ini peserta yang telah mengikuti program pembekalan kewiraushaan tidak secara langsung dapat menerima biaya rintisan usaha, hal tersebut disebabkan pencairan biaya rintisan dilakukan di Perangkat Daerah masingmasing, peserta pembekalan kewirausahaan biasanya menerima biaya rintisan usaha tiga bulan menjelang pensiun. Hal tersebut sesuai dengan teori Kirkpatrick (2007:23) "Reaksi adalah lembaran kepuasan pelanggan, bertujuan untuk mendapatkan masukan dan komentar peserta terhadap program pembekalan". Banyaknya masukan dan komentar dari peserta agar biaya rintisan usaha diberikan setelah program pembekalan kewirausahaan.

\section{Equite (pemerataan)}

Melihat dari fenomena di lapangan dari hasil wawancara peneliti dengan beberapa informan, maka secara umum dapat peneliti simpulkan bahwa pelaksanaan program pembekalan kewirausahaan di Lingkungan Pemerintah Daerah Provinsi Jawa Barat belum merata dalam keikutsertaan program pembekalan. Hal itu disebabkan masih banyak guru SMA/SMK dari Dinas Pendidikan yang belum bisa mengikuti program pembekalan kewirausahaan. Hal tersebut sama halnya dengan teori dari Kirkpatrick (2007:23) “ Dampak adalah Pengaruh yang akan mendatangkan akibat positif maupun negatif". Guru SMK/SMA adalah bagian dari Pemerintah Provinsi Jawa Barat, apabila tidak diikutsertakan akan berdamak negatif bagi pemerintah Provinsi Jawa Barat.

\section{Responsiveness (Responsivitas)}

Pelaksanaan program pembekalan kewirausahaan aparatur pra purnabakti 
di lingkungan Pemerintah Daerah Provinsi Jawa Barat mendapatkan respons baik dari semua aparatur. Hal tersebut sesuai dengan teori Lester dan Stewart dalam Nugroho (2011:647) " evaluasi ditunjukkan untuk melihat sebab-sebab kegagalan suatu kebijakan dan untuk mengetahui apakah kebijakan yang telah dirumuskan dan dilaksanakan dapat menghasilakan dampak yang diinginkan. Dengan tingginya antusias pesertauntukmengikuti program pembekalan kewirasuahaan harus berdampak kepada tujuan dengan program pembekalan.

\section{Appropriatness (ketepatan)}

Pembekalan kewirausahaan di Lingkungan Pemerintah Daerah Provinsi belum sepenuhnya tepat sasaran khususnya kepada peserta pembekalan kewirausahaan yang bukan lagi usia produktif, sehingga pergerakan dari aparatur tersebut cukup terbatas. Kemudian program pembekalan kewirausahaan tersebut tidak sesuai dengan minat bakat, sehingga materi yang disampaikan semuanya sama. Akan tetapi dengan adanya program pembekalan kewirausahaan antusias aparatur sangat tinggi untuk mengikuti kegiatan tersebut, karena aparatur menyangkal bahwa program pembekalan merupakan suatu bentuk perhatian dari pemerintah Provinsi Jawa Barat. Hal tersebut sesuai dengan Cronbach (1960) dalam bukunya yang berjudul Designing evaluator of education and social programme "evaluasi merupakan suatu proses terus menerus, sehingga di dalam proses kegiatannya dimungkinkan untuk merevisi bila dirasakan adanya sesuatu kesalahan". Dalam hal ini pemerintah Provinsi Jawa Barat harus memperbaiki apa yang menjadi kekurangan di program pembekalan kewirausahaan.

\section{SIMPULAN}

Berdasarkan hasil penelitian dan pembahasan yang telah dilakukan, maka dapat ditarik simpulan sebagai berikut.

1. Hasil evaluasi pelaksanaan program pembekalan kewirausahaan di Lingkungan Pemerintah Daerah Provinsi Jawa Barat belum optimal. Hal tersebut ditunjukkan oleh beberapa kriteria dimensi yakni, Efektivitas, Efisiensi, kecukupan, pemerataan, dan ketepatan belum berjalan secara optimal. Hanya saja resposivitas yang sudah cukup baik dari semua aparatur karena setiap pelaksanaan program pembekalan kewirausahaan antusias peserta sangat tinggi

2. Program pembekalan kewirausahaan yang cocok diterapkan di lingkungan Pemerintahan Daerah Provinsi Jawa Barat adalah sebagai berikut.

a. Program pembekalan kewirausahaan hanya diikuti oleh aparatur yang memiliki keahlian dan keterampilan.

b. Setiap aparatur yang telah mendapatkan biaya rintisan usaha harus membuat laporan pertanggungjawaban.

c. Biaya rintisan usaha diberikan langsung setelah mengikuti program pembekalan kewirausahaan.

d. Program pembekalan kewirausahaan harus memenuhi persyaratan yang telah ditentukan.

e. Peserta program pembekalan kewirausahaan akan dikelompokkan sesuai dengan minat bakat masingmasing peserta.

\section{SARAN}

a. Agar program pembekalan kewirausahaan berjalan efektif, maka Pemerintah Provinsi Jawa Barat perlu menyeleksi aparatur yang akan mengikuti pembekalan, jadi tidak semua aparatur diikutsertakan. 
b. Aparatur yang telah mendapatkan biaya rintisan usaha harus ada laporan pertanggungjawabannya kepada Pemerintah Provinsi Jawa Barat terkait penggunaan uang tersebut dan harus ada asesor untuk monitoring dan menilai aparatur yang memiliki keahlian.

c. Biaya rintisan usaha di berikan ketika masih aktif bekerja akan menambah semangat dari aparatur untuk melaksanakan usaha, selain itu ketika masih aktif memudahkan aparatur menjalin relasi.

d. Pemerintah provinsi tidak memberikan biaya rintisan usaha kepada aparatur yang tidak memiliki keahlian dan keterampilan usaha, karena biaya rintisan usaha adalah penghargaan bukan hak.

e. Memperbaiki dari segi efektivitas dalam menyeleksi peserta, pemantauan bagi aparatur yang sudah mendapatkan biaya rintisan usaha, pemerataan dengan melibatkan semua aparatur (guru SMA/ SMK).

f. Dalam pelaksanaan program pembekalan kewiraushaan harus dikelompokkan sesusai minat bakat, sehingga aparatur tidak perlu mengikuti materi yang tidak sesuai dengan minat bakat.

\section{DAFTAR PUSTAKA}

Abdul Rahmat, Suyanto. 2016. Post Power Syndrom dan Perubahan Perilaku Sosial dan Pensiunan Guru. Psympathic: Jurnal Ilmiah Psikologi, Vol 3 (1), p 77-94.

Abdul Rahmat, Sulichin Analis Kebijakan Dari Formulasi ke Implementasi Kebijakan Negara, Bumi Aksara, Jakarta.

Agustino, Leo, 2006, Politik dan Kebijakan Publik, AIPI, Bandung.

Arifin Zainal. 2013. Evaluasi Pembelajaran. Bandung:PT Remaja Rosdakarya
Arikunto dan Jabar. 2009 Evaluasi Program Pendidikan. Jakarta. Bumi aksara

Arikunto, Suharsimi. 2013. Prosedur-Prosedur Penelitian. Jakarta:Rineka Cipta

Asrul, Rusyidi, Rosnita. 2014. Evaluasi Pembelajaran. Bandung. Citapustaka Media

A.W Widjadja. 1995. Administrasi kepegawaian. Jakarta: Rajagrapindo Persada

Bongdan, Robert dan Taylor. 1992. Pengantar Metode Penelitian Kualitatif. Surabaya: Usaha Nasional.

Bungin, Burhan. 201 1. Penelüian Kualitatif. Jakarta: Kencana Predana Media Group.

Creswell, W. Jhon. 2016. Research Design Pendekatan Kualitatif, Kuantitatif dan Mixed. Yogyakarta: Pustaka Pclajar.

Cronbach, L. J. (J 960). Esentials of Psycholocal Testing. New York: Harper \& Row Publisher

Donald L. Kirkpatrick dan James D. Kirkpatrick. 2005. Evaluating Training Programs:The Four Levels. San Fransisco: BerrettKoehlcr Publishers Inc

Dunn, W. 2000. Pengantar Analisis Kebijakan Publik. Yogyakarta:Gajah Mada University Press, Yogyakarta.

Dunn, W. 2003. Pengantar Analisis Kebijakan Publik, Edisi Kedua :Gajah Mada University Press, Yogyakarta

Dunn, W. 2008, Public Policy Analisis An Introduction: Fourth Editions, Pearson Prentice Hall, New Jersey.

Dye, R. nomas, 1978, Understanding Public Policy, Prentice Hall, Inc, Englewood Cliffs, New Jersey

Egon D Gall, Joyce P Gall dan Walter R Borg. Education Research: An Introduction (Boston:Pearson Education Inc, 2003).

Hadi, Abdul. 2017. Rancangan Sistem Jaminan Pensiun dan Hari Tua pegawai Negeri Sipil (PNS). Jakarta: Pusat Pengkajian dan Penelitian Kepegawaian Badan Kepegawaian Negara.

Hurlock E B. 1993. Psikologi Perkembangan:suatu Pendekatan sepanjang rentang kehidupan (edisi kelima). Jakarta: Erlangga. 
Irfan M, 2001, Prinsip-prinsip Perumusan Kebijakan Negara, Bumi Aksara, Jakarta.

Iswanti, Sri. Hiryanto dan Fathiyah, Kartika Nur, 2014. Pengembangan Materi Pelatihan Menghadapi Pensiun Bagi Karyawan Universitas Negeri Yogyakarta. Jurnal Penelitian Humaniora, Vol 19 (1), P 96-103

Moleong, Lexy. (2002). Metodologi Kualitatif Bandung:PT. Remaja Rosdakarya.

Mulyana D 2001. Metodologi penelitian Kualitatif, Paradigma Ilmu Komunikasi dan Ilmu Sosial. Bandung: Rosdakarya.

Munthe. 2015. Pentingnya Evaluasi Program di Institusi Pendidikan: Sebuah Pengantar, pengertian, Tujuan dan Manfaat. Tangerang: FIP Universitas Pelita Harapan.

Nugroho, Rian D, 2011, Kebijakan Publik: Formulasi, Implementasi dan Evaluasi, PT. Grasindo. Jakarta.

Retno Dewanti.2008. Kewirausahaan.Jakarta. Mitra Wacana Media

Saputra Hanif Rahmat dan Sagala, Ella Jauvani. 2016. Pengaruh Program Persiapan Pensiun Saputra terhadap Kesiapan Pensiun Kałyavvan di PT Krakatau Steel (Persero) tbk. E-Proccering of Management. voi 3 (3). P 2991-2998.

Sedarmayanti, 2002. Rencana Pembelajaran dan Bahan Ajar Human Resource Development (Pengembangan Sumber Daya Manusia). Yogyakarta: Deepublish

Sedarmayanti, 2007. Manajemen Sumber Daya Manusia Reformasi Birokrasi dan Manajemen Pegawai Negeri Sipil. Bandung:Refika Aditama sedarmayanti, 2009.

Sedarmayanti, 2009. Sumber Daya Manusia dan Produktivitas Kerja. Bandung: Mandar Maju

Sefrina, Fauziah dan Latipun. 2016. Hubungan Dukungan Keluarga dan Keberfungsian Sosial Pada Pasien Skizofrenian Rawat Jalan. Jurnal Psikologi Terapan. VOI 04 (02) $-140-160$
Simanjuntak, Payaman J .2005. Manajemen Sumber Daya Manusia. Jakarta: FE UI.

Sitiatava Rizema Putra. 2013. Desain Evaluasi Belajar Berbasis Kinerja. Yogyakarta.Diva Press

Soekidjo Notoatmodjo. 1997. Pengantar Pendidikan dan Perilaku Kesehatan. Yogyakarta:Andi Offset

Stufflebeam, D. L. et al. 1971. Educational Evaluation and Decision Making Fourth Printing.Illinois: F.E Peacock Publishers, Inc.

Sugiyono, 2014, Memahami Penelitian Kualitatif. Bandung; alfabeta

Sugiyono. 2017. Metode Penelitian Kuantitatif, Kualitatif, dan R\&D. Bandung: Alfabeta, CV.

Suharsimi Arikunto. 2010. Prosedur Penelitian Suatu Pendekatan Praktik.Jakarta;Rineka Cipta

Sumaryadi, I Nyoman, 2005, Perencanaan Pembangunan Daerah Otonomi dan Pemberdayaan Masyarakat. Cipta Utama, Jakarta

Sunhaji.2014. Konsep Manajemen Kelas dan Implikasinya dalam Pembelajaran: Jurnal Kependidikan, Vol.ll no 2

Syafrizal, 2009, Teknk Praktis Penyusunan Perencanaan Pemerintah Daerah, Beduose Media, Jakarta.

Tayibanapis, Farida Yusuf P, 1997, This Relation of Economic Development, Wesley Longman Limited, London.

Yulinda Erna Suryani, Desember 2017. Pemetaan Kualitas Empirik Soal Ujian Akhir Semester Pada Mata Pelajaran Bahasa Indonesia SMA di Kabupaten Sleman. Jurnal Evaluasi Pendidikan. Vol 21, No 2 (147-157)

\section{Peraturan Perundang-Undangan}

Undang-Undang Nomor 5 Tahun 2014 tentang aparatur Sipil Negara 
Peraturan Pemerintah Nomor 11 Tahun 2017 tentang Manajemen PNS

Peraturan Gubernur Jawa Barat Nomor 70 Tahun 2018 tentang Kesejahteraan Aparatur di Lingkungan Pemerintah Daerah Provinsi Jawa Barat 